\title{
THE EFFECT OF NUMBERED HEADS TOGETHER (NHT) LEARNING METHODS ON COMMUNICATION SKILLS OF STUDENTS IN CLASS IV ELEMENTARY SCHOOL
}

\author{
Fedik Novibriawan $^{1}$, Nurhasanah ${ }^{2}$, I Nyoman Karma ${ }^{3}$ \\ ${ }^{1,2,3}$ Elementary Education Study Program, Faculty of Teacher Training and Education, Universitas Mataram, Mataram, \\ Indonesia
}

\section{Article Info}

\section{Article history:}

Received: 13-04-2021

Revised: 22-07-2021

Published: 30-09-2021

\section{Keywords:}

Cooperative model

NHT

Communication skill

ABSTRACT

This study aims to determine the effect of the Numbered Heads Together type of cooperative learning model on students' communication skills in class IV social studies content at SDN Gugus 01 Pringgarata District, Central Lombok in the 2018/2019 academic year. This research is an experimental study of the type of Quasi Experimental Design Type of Nonequivalent Control Group Design. The sampling technique used is Purvosive Sampling, which considers all kinds of aspects in determining the sample. The method of data collection is observation in the form of student observation sheets or direct observations and rubrics as a reference for assessment. The data obtained were then analyzed using the t-test polled variance formula to determine the effect of the use of the Numbered Heads Together type of cooperative learning model on students' communication skills. Based on the post-test results, the average value of students' communication skills in the experimental class was 75.9 and the control class was 67.8. The results of the t-test calculation obtained that the tcount value is greater than ttable, namely the tcount value is 2.84 while the ttable is 2.006 at a significance level of $5 \%$. Thus, it can be concluded that $\mathrm{Ha}$ is accepted and Ho is rejected, which means that there is a positive and significant effect between the Numbered Heads Together type of cooperative learning model on students' communication skills in social studies content for class IV SDN Gugus 01 Pringgarata sub-district, Central Lombok in the 2018/2019 academic year.
\end{abstract}

This is an open access article under the CC BY-SA license.

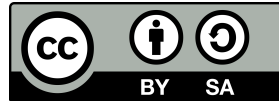

\section{Corresponding Author:}

Fedik Novibriawan,

Elementary Education Study Program, Faculty of Teacher Training and Education, Universitas Mataram,

Jl. Brawijaya No. 22, Mataram, Indonesia.

Email: fediknovibriawan2@gmail.com

\section{INTRODUCTION}

School is one of the great educational facilities for children to get a valuable experience. At school, there are many values of attitudes, knowledge, and skills that are very useful. Attitude and character values need integration in learning, starting from elementary school (Akbar, 2010). Social values can be identified by observing social values based on the characteristics of social interactions in the learning process (Rachman, 2016).

In elementary school (SD) learning, social studies subjects are the main subjects in the education 
curriculum in Indonesia, including at the elementary school (SD) level. In the 2013 curriculum the subjects were changed to learning content, where the content of the 2013 curriculum implementation made all subjects in basic education implemented with integrative thematics (Syaifudin, Rokhman, \& Zulaeha, 2017). Social studies learning content that has been prepared using the 2013 curriculum with the hope that students are trained to be able to interact well and practice social cooperation (Kristiantari, 2015). Social studies content is very important and interesting to learn, especially when interacting socially in society. Through social science learning, character education values can be integrated through the materials studied (Afandi, 2011).

According to Havighurst, the developmental tasks of elementary school age children include: 1) Mastering the physical skills needed in games and physical activity, physical skills and physical activity need to be developed especially in socializing; 2) Fostering a healthy life, the essence of healthy living here is to establish good relations between them; 3) Learn to get along and work in groups, humans cannot live alone, they need other people; 4) Learn to carry out social roles according to gender, men and women have their respective roles and have certain limitations; 5) Learn to read, write, and count in order to be able to participate in society, in our social life we will never be separated from social values, sometimes we read something to get information, sometimes write something and so on; 6) To obtain a number of concepts needed to think effectively, the social studies content is first introduced to a concept from the concept which is then developed.

In an effort to achieve each of these developmental tasks, teachers are always required to provide assistance in the form of creating a peer environment that teaches physical skills, communication skills and implements learning. Provide opportunities for students to learn to get along and work with peers so that their social personality develops, and carry out learning that can develop values, so that students are able to make stable choices and become a guide for themselves. Aspects of student development will affect the teaching and learning process in schools (Latifa, 2017).

The role of the teacher in schools is very important in addition to transforming the sciences of a teacher's task as well as to teach, guide, direct, train, assess, evaluate students on the formal education path, and teach the values of social norms that exist in society. The important role of teachers in developing student communication skills such as, teachers as models, teachers as motivators, teachers as mentors, teachers as facilitators, and teachers as educators (Budiono \& Abdurrohim, 2020). In a democratic learning atmosphere, there are freedoms that are obtained by students such as being free to express opinions in group discussions and being free to communicate the results of their discussions. A democratic learning atmosphere and all students can take an active role in communicating the results of their discussions will be able to influence optimal learning outcomes (Siregar, Wardani, \& Hatika, 2017). The use of approaches in the learning process can also increase student activity (Novianingsih, 2016).

Communication skills are very important to be developed in the learning process, because communication skills are also to train students' self-confidence when in the learning process. The use of learning models can improve students' communication skills (Oktavianingsih, 2018). It is important to conduct this research to measure and find out how much influence the Numbered Heads Together type of cooperative learning model has on students' communication skills.

Based on direct observations and interviews with teachers on 20 and 23 July 2018 in grade IV SDN (State Elementary School) Cluster 01 Pringgarata District, Central Lombok, for the 2018/2019 academic year, there were almost the same answers and the same problem regarding the condition of students when implementing group discussion learning and especially the use of the learning model used by the teacher. The lack of development of learning models that are group discussion in nature is a problem that cannot be left alone, the lack of active students in group discussions, there are still many students who play around in the group discussion process, the lack of activeness of all students in group discussions and the lack of courage among students. In communicating the results of their discussions or opinions, only smart students are active in the learning process, both in the discussion process, and when communicating the results of their discussions.

The problem in this study is "Is there an effect of the Numbered Heads Together Cooperative Learning Model on Students' Communication Skills in Social Studies Content for Class IV SDN Gugus 01 Pringgarata District, Central Lombok, 2018/2019 Academic Year"?. The purpose of this study was "To determine the effect of the Numbered Heads Together Cooperative Learning Model on Students' Communication Skills in Social Studies Content for Class IV SDN Gugus 01, Pringgarata District, Central Lombok, 2018/2019 Academic Year". 


\section{RESEARCH METHOD}

This research is an experimental research type. The approach used in this research is descriptive quantitative. The research design used in this study was a Quasi Experimental Design research design, because in this study the researcher wanted to measure the influence of the treatment group and then compare it with the group without treatment.

This research was carried out in the even semester, namely in April 2019 for the 2018/2019 academic year at SDN Gugus 01, Pringgarata District, Central Lombok. The population in this study is all class IV SDN located in cluster 01, Pringgarata District, while the sampling technique used in this study is Non-probability sampling, which is a sampling technique that does not provide equal opportunities for each element (member) of the population to be selected as sample members (Sugiyono, 2016). Determination of the sample using purposive sampling technique because it considers various things such as the number of students, the number of teachers, student characteristics, school characteristics, the curriculum used and the ability of students who first tested the equality of students' abilities. The sample in this study amounted to 56 students, consisting of 30 students in the experimental class and 26 students in the control class.

The data collection method used in this research is the observation method. The pre-test and post-test scores in this study were obtained using the observation method, namely by means of a checklist in accordance with predetermined aspects. Before the instrument is used as a data collection tool in the field, it is necessary to do an expert test first. The data analysis technique in this research is in the form of descriptive-quantitative analysis.

\subsection{Descriptive test}

Descriptive analysis was conducted to describe the effect of the NHT cooperative learning model on students' communication skills in social studies class IV at SDN Gugus 01, Pringgarata District, Central Lombok. Descriptive analysis in this study uses descriptive statistical analysis techniques.

\subsection{Data normality test}

The data normality test was conducted to determine whether the data was normally distributed or not. Testing can be done with the Chi-Square formula, the test criteria if the significance is greater than 0.05 then the data is said to be normally distributed.

\section{RESULT AND DISCUSSION}

\subsection{Descriptive Analysis}

Table 1. Pre-test and post-test of students' communication skills

\begin{tabular}{lccccc}
\hline Class & $\mathrm{N}$ & Observation & Highest Score & Lowest Score & Mean \\
\hline Experiment & 30 & Pre-test & 82 & 53 & 64,5 \\
& 30 & Post-test & 90 & 61 & 79,3 \\
\hline Control & 26 & Pre-test & 79 & 50 & 68,4 \\
& 26 & Post-test & 82 & 57 & 71,6 \\
\hline
\end{tabular}

Based on the table above, the data collection method using the observation method can show that the experimental group of 30 students obtained the highest pre-test score of 82 and the lowest was 53 with an average score of 64.5, while the post-test score in the experimental class, the highest score was 92 and the lowest was 61 with an average value of 79.3. Furthermore, in the control class, which consisted of 26 students, the highest pre-test score was 79 and the lowest was 50 with an average score of 68.4, while the post-test score in the control class was 82 and the lowest was 82.57 with an average rating of 71.6.

\subsection{Normality test}

Table 2. The results of normality test

\begin{tabular}{lcccc}
\hline Class & Observation & $\chi_{\text {value }}^{2}$ & $\chi_{\text {table }}^{2}$ & Decision \\
\hline Experiment & Pre-test & 10.22 & 12.59 & Normaly distributed \\
& Post-test & 10.74 & 12.59 & Normaly distributed \\
\hline Control & Pre-test & 8.32 & 12.59 & Normaly distributed \\
& Post-test & 8.92 & 12.59 & Normaly distributed \\
\hline
\end{tabular}


From the results of the calculation of the normality test, in the table above, it can be concluded that in the experimental class at the time of pre-test using the observation sheet obtained $\chi_{\text {value }}^{2}$ of 10.22 and $\chi_{\text {table }}^{2}$ of 12.59 can be concluded normally distributed, in the control class at the time of pre-test by using the observation sheet obtained $\chi_{\text {value }}^{2}$ of 8.32 and $\chi_{\text {table }}^{2}$ of 12.59 can be concluded normally distributed, in the experimental class at the time of post-test using the observation sheet obtained $\chi_{\text {value }}^{2}$ of 10.74 and $\chi_{\text {table }}^{2}$ of 12.59 can be concluded normally distributed, in the control class at the time of post-test using the observation sheet obtained $\chi_{v a l u e}^{2}$ of 8.92 and $\chi_{\text {table }}^{2}$ of 12.59 can be concluded normally distributed.

\subsection{Homogenity Test}

Table 3. The results of homogenity test

\begin{tabular}{lcccc}
\hline Observation & Class & $\mathrm{F}_{\text {value }}$ & $\mathrm{F}_{\text {table }}$ & Decision \\
\hline Pre-test & $\begin{array}{c}\text { Experiment } \\
\text { Control }\end{array}$ & 1.02 & 1.78 & Homogen \\
\hline Post-test & $\begin{array}{c}\text { Experiment } \\
\text { Control }\end{array}$ & 1.15 & 1.74 & Homogen \\
\hline
\end{tabular}

The table above shows that the $\mathrm{F}_{\text {value }}$ of 1.02 is smaller than the $\mathrm{F}_{\text {table }}$ of 1.78 , with $\mathrm{db}$ for the numerator $=25$ and $\mathrm{db}$ for the denominator $=29$ at a significance level of $5 \%$. This means that the status of the experimental and control class variants comes from a homogeneous variant. The table above shows that the $\mathrm{F}_{\text {value }}$ of 1.15 is smaller than $\mathrm{F}_{\text {table }} 1.74$, with $\mathrm{db}$ for the numerator $=29$ and $\mathrm{db}$ for the denominator $=25$ at $\mathrm{a}$ significance level of $5 \%$. This means that the status of the experimental class and control class variants come from homogeneous variants.

\subsection{Hypothesis Test}

Table 4. Hypothesis test results

\begin{tabular}{lcccccc}
\hline Group & $\mathrm{N}$ & Mean & $\mathrm{SD}$ & Varians & $\mathrm{t}_{\text {value }}$ & $\mathrm{t}_{\text {table }}$ \\
\hline Experiment & 30 & 75.9 & 31.42 & 987.57 & 2.84 & 2.006 \\
Control & 26 & 67.8 & 29.26 & 855.68 & & \\
\hline
\end{tabular}

In the table above, it can be seen that $\mathrm{t}_{\mathrm{value}}>\mathrm{t}_{\text {table }}$ that is, $2.84>2.006$ at a significance level of $5 \%$ with degrees of freedom $(\mathrm{dk})=n 1+n 2-2=30+26-54$. In accordance with the criteria for testing the hypothesis, namely $t_{\text {value }}>t_{\text {table }}$ then, $H_{0}$ is rejected and $H_{a}$ is accepted. This shows that there is a positive and significant effect between the Numbered Heads Together type of cooperative learning model on students' communication skills in the class IV social studies content at SDN Gugus 01 Pringgarata District, Central Lombok in the 2018/2019 academic year. The analysis process used in this study is to measure the post-test results using the t-test polled variance formula in both the experimental class and control class and then compare the results.

\subsection{Effect Size test}

Based on the results of the calculation of the effect size of the post-test data on communication skills that have been carried out, it is obtained that the influence of the independent variable on the dependent variable is 0.27 . This means that the effect of the Numbered Heads Together type of cooperative learning model on students' communication skills in this study is categorized as small.

\subsection{Coefficient of Determination Test}

The results of the calculations that have been done, the value of $r_{2}$ is 0.018 while the coefficient of determination (KD) is $1.8 \%$. This states that the effect of the NHT Numbered Heads Together type of cooperative learning model on students' communication skills is $1.8 \%$ and the remaining $98.2 \%$ is determined by other variables or external factors that can affect the course of the experiment, such as less than the maximum when applying the Numbered Heads method. Together in learning during the experiment and the less than optimal learning process carried out by researchers at the time of research. 


\section{CONCLUSION}

Based on research conducted on fourth grade students of SDN Gugus 01 Pringgarata District, Central Lombok about the effect of the Numbered Heads Together type of cooperative learning model using quantitative data analysis $t$ test. The value of $t_{\text {value }}$ is 2.84 while $t_{\text {table }}$ is 2.006 at a significance level of $5 \%$. Thus, $\mathrm{t}_{\text {value }}(2.84) i \mathrm{t}_{\text {table }}$ (2.006) so that in this study Ha is accepted and Ho is rejected so it can be concluded that there is an effect of the Numbered Heads Together type of cooperative learning model on students' communication skills in social studies content for class IV SDN Gugus 01 Pringgarata District, Central Lombok for the 2018/2019 school year. While the results of the calculation of the effect size obtained 0.27. This means that the communication skills of fourth graders at SDN Gugus 01 Pringgarata District, Central Lombok in the 2018/2019 academic year are influenced by the Numbered Heads Together type of cooperative learning model of 0.27 and in the effect size assessment criteria, 0.27 is included in the influence small.

And the results of the calculation of the coefficient of determination (KD) obtained $1.8 \%$. This states that the effect of the Numbered Heads Together type of cooperative learning model on students' communication skills is $1.8 \%$ and the remaining $98.2 \%$ is determined by other variables or external factors that can affect the course of the experiment, such as less than optimal when applying the Numbered Heads Together method. in learning during experiments and less than the maximum learning process carried out by researchers at the time of research.

\section{REFERENCES}

Afandi, R. (2011). Integrasi Pendidikan Karakter Dalam Pembelajaran IPS Di Sekolah Dasar. PEDAGOGIA: Jurnal Pendidikan, 1(1), 85.

Akbar, S. (2010). Model Pembelajaran Nilai Dan Karakter Berbasis Nilai-Nilai Kehidupan Di Sekolah Dasar. Jurnal Ilmu Pendidikan, 1(1), 46-54.

Budiono, H., \& Abdurrohim, M. (2020). Peran Guru Dalam Mengembangkan Keterampilan Komunikasi (Communication) Siswa Kelas V Sekolah Dasar Negeri Teratai. Jurnal IKA PGSD (Ikatan Alumni PGSD) UNARS, 8(1), 119.

Kristiantari, R. (2015). Analisis Kesiapan Guru Sekolah Dasar dalam Mengimplementasikan Pembelajaran Tematik Integratif Menyongsong Kurikulum 2013. JPI (Jurnal Pendidikan Indonesia), 3(2), 460-470.

Latifa, U. (2017). Aspek Perkembangan pada Anak Sekolah Dasar: Masalah dan Perkembangannya. Journal of Multidisciplinary Studies, 1(2), 185-196.

Novianingsih, H. (2016). Pendekatan Pembelajaran Aktif, Kreatif, Efektif, Dan Menyenangkan Dalam Pembelajaran Matematika Sekolah Dasar. Jurnal Pendidikan Guru Sekolah Dasar, 1(1), 1-11.

Oktavianingsih, E. (2018). Meningkatkan Keterampilan Berkomunikasi Verbal Anak Usia Dini Melalui Pembelajaran Berbasis Proyek. In Kmp education research conference.

Rachman, M. (2016). Pengembangan Pendidikan Karakter Berwawasan Konservasi Nilai-Nilai Sosial. jurnal Forum Ilmu Sosial (FIS), Universitas Negeri Semarang, Jawa tengah Indonesia. FIS (Forum Ilmu Sosial), 40(1), 1-15.

Siregar, P. S., Wardani, L., \& Hatika, R. G. (2017). Penerapan Pendekatan Pembelajaran Aktif Inovatif Kreatif Efektif Dan Menyenangkan (Paikem) Pada Pembelajaran Matematika Kelas Iv Sd Negeri 010 Rambah. Jurnal Pemikiran Dan Pengembangan Sekolah Dasar (JP2SD), 5(2), 743.

Sugiyono. (2016). Metode penelitian kuantitatif kualitatif dan $R \& D$. Bandung: Alfa Beta.

Syaifudin, A., Rokhman, F., \& Zulaeha, I. (2017). Pengembangan Strategi Pembelajaran Tematik Integratif pada Mata Pelajaran Bahasa Indonesia Jenjang Pendidikan Dasar. Jurnal Inovasi Pembelajaran Karakter (JIPK), 2(2), 1-6. 